\title{
Modulation of nearshore harmful algal blooms by in situ growth rate and water renewal
}

\author{
G. Basterretxea ${ }^{1, *}$, E. Garcés ${ }^{2}$, A. Jordi ${ }^{3}$, S. Anglès ${ }^{2}$, M. Masó ${ }^{2}$ \\ ${ }^{1}$ Institut Mediterrani d'Estudis Avançats, IMEDEA (UIB-CSIC), Miquel Marqués 21, 07190 Esporles, Baleares, Spain \\ ${ }^{2}$ Institut de Ciències del Mar (CMIMA-CSIC), Pg. Maritim de la Barceloneta 37-49, 08003 Barcelona, Spain \\ ${ }^{3}$ Marine Sciences Research Center, State University of New York, Stony Brook, 11794 New York, USA
}

\begin{abstract}
Species belonging to the genera Alexandrium and Gymnodinium are amongst the dinoflagellates that regularly cause massive coastal phytoplankton blooms along Mediterranean beaches. These episodes encompass a variety of factors favouring bloom development, including near-shore nutrient enrichment, enhanced growth and low water renewal. During the summer of 2003 the development of a bloom was monitored at 2 nearby beaches, Peguera and Santa Ponça, located at the head of Santa Ponça Bay (Mallorca). Both sites are under the influence of the same physical regime - which is mainly wind-forced - and present relatively high inorganic nutrient concentrations for Mediterranean waters during summer (mean dissolved inorganic nitrogen $>1.2 \mu \mathrm{M}$ and $\mathrm{PO}_{4}>0.18 \mu \mathrm{M}$ ). Total dinoflagellate abundance exhibited a similar trend at both beaches, with remarkable outbursts in late June $\left(>8 \times 10^{6}\right.$ cells $\left.\mathrm{l}^{-1}\right)$. Water exchange calculations, based on 3D numerical modeling, yielded low average renewal rates at both sites $\left(<0.08 \mathrm{~d}^{-1}\right)$, and cell growth estimations suggested a significant increase in the specific growth rates during the blooming season associated with the seasonal temperature variation. We postulate that both the increased growth rates and the low wind-induced water renewal times are complementary factors and are of key relevance to the modulation of these blooms. Diagnostic analyses using a simple phytoplanktonzooplankton $(P Z)$ model allowed us to observe the effect of growth rate and water renewal on bloom dynamics, and to identify a threshold condition for bloom occurrence.
\end{abstract}

KEY WORDS: Harmful algal bloom · Water renewal $\cdot$ Growth · Model · Mediterranean Resale or republication not permitted without written consent of the publisher

\section{INTRODUCTION}

Dense blooms of phytoplankton are a widespread phenomenon of the global coastal ocean. They develop in response to favorable conditions for cell growth and accumulation, and are commonly grouped as harmful algal blooms (HABs) because of their deleterious effects. In contrast to large-scale blooms that are dominated by mesoscale circulation, Mediterranean HABs are a more localized phenomenon commonly related to areas of constrained dynamism, such as bays, lagoons, ports, beaches and estuaries (Garcés et al. 1998, Vila et al. 2001, Lopez-Flores et al. 2006). In these areas, enhanced growth of phytoplankton not only leads to a perceivable water discoloration along the shoreline but also to a deterioration in water quality. Other unprecedented ecological effects in the Mediterranean, such as fish kills (Garcés et al. 2006) and risks to human health (Penna et al. 2006), have been attributed to toxic algal proliferations in recent years.

The definition of what it is considered to be a bloom varies, and it is based on several criteria such as cell abundance, biomass, physiological characteristics (e.g. growth rates), toxicity levels and deleterious effects on human activities etc. Moreover, the definition of what is considered to be a bloom rarely includes references to biological and environmental conditions leading to that state (Cartensen et al. 2004). Given that a bloom represents a deviation from the normal cycle of biomass (Parker \& Tett 1987), a summer bloom can tentatively be considered to have occurred in the coastal waters of the western Mediterranean (Balearic Islands) 
when the chlorophyll concentration reaches values of $1 \mathrm{mg} \mathrm{m}^{-3}$ and/or when cell densities are above $10^{4}$ cells $\mathrm{l}^{-1}$, which is usually concomitant with sustained coastal water temperatures exceeding $21^{\circ} \mathrm{C}$. These biomass values are high when compared with the standing stocks observed in coastal waters (e.g. $<0.4 \mathrm{mg} \mathrm{m}^{-3}$, Jansá 1994), and represent a stage where the proliferation begins to become perceptible as a change in water color.

Despite the fact that in some cases the proliferation of algae may have a natural origin, it is considered that coastal blooms are an emerging problem that could be related to nutrient enrichment of coastal waters (Duarte et al. 2000). Intensive urbanization and recreational use of coastal watersheds has resulted in a remarkable increase in sources of nutrients along the Mediterranean coasts. This cultural eutrophication generates a contrast between coastal waters and the open ocean where, owing to summer stratification and nutrient depletion, oligotrophic conditions prevail in the upper layer. Nutrient-rich coastal environments of the Mediterranean Sea and, in particular, semienclosed areas with low turbulence levels constitute a new and unique environment for which several phytoplankton species with harmful effects may become dominant. Vertically migrating dinoflagellates with complex but distinct life-cycles, such as the genus Alexandrium and Gymnodinium, attain high abun-

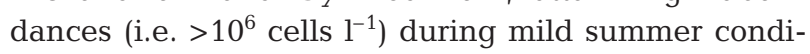
tions. Proliferations of species of either or both genera are becoming common along the coasts of the Mediterranean (Garcés et al. 2005), particularly in areas of restricted water exchange such as pocket beaches and ports where their swimming ability allows for the maintenance of critical viable patches, even at early bloom stages.

The intricate coastal geomorphology of the Balearic Islands, with its numerous inlets and pocket beaches and a dynamic tourism industry that has promoted the construction of ports along the shore, has provided a favorable environment for HAB expansion. Although enrichment is observed in these areas, evaluation of the nutrient inputs is difficult owing to their diffuse nature. Moreover, when nutrients are added from anthropogenic sources, relative ratios may be skewed in addition to absolute concentration, favoring the proliferation of particular groups (Hodgkiss 1997). In addition, the exact form of the nutrients (e.g. dissolved organic nitrogen vs. ammonium vs. nitrate) can be a determinant in phytoplankton species selection (Collos et al. 2004).

Even though most of the factors involved in the Mediterranean nearshore algal outbreaks are known, the mechanisms that underpin their occurrence are not yet well established. Terrestrial nutrient loads, toxin production, species diversity, grazing pressure, life cycles and strategies, physical transport, mixing and other factors have all been used to explain the onset and evolution of phytoplankton blooms. Differences in bloom-controlling mechanisms are also reflected in the species composition, as reported for other areas (Smayda \& Reynolds 2003). It is therefore challenging to understand how all of these different factors combine to stimulate and govern outbreaks.

In the case of coastal blooms in semi-enclosed systems, it is generally accepted that the rate of planktonic cell growth must exceed the rate of cell dispersion in order for bloom formation to occur (e.g. Figueiras et al. 2006). Knowledge of the variation of both phytoplankton growth rates and water renewal is thus fundamental to our understanding of the processes and mechanisms leading to bloom formation and to their maintenance at these sites. The contribution of each of these 2 ecosystem variables to nearshore bloom formation can be analyzed with the use of simplified biological models. Recognizing that simplified algorithms are generally unable to represent all of the variability of the system, they are intended to robustly present the essential foodweb dynamics and to analyze the mechanisms that more sophisticated approaches are unable to clarify. In this sense, simple models provide the necessary framework for exploring different aspects of HAB occurrence (e.g. Franks 1997, Sarkar et al. 2006).

This study evaluates the importance of dinoflagellate growth rate and coastal water exchange in the modulation of dinoflagellate abundance in Mediterranean nearshore blooms. The analysis is based on field measurements of biomass, growth rates and nutrients, and on numerical estimations of the wind-induced water renewal. In order to identify the factors that control bloom formation and, in particular, the effect of growth rates and residence time on bloom modulation, we formulated a simple phytoplankton-zooplankton (PZ) model with an additional factor to account for the advective losses produced by water renewal.

\section{MATERIALS AND METHODS}

Biological sampling. The study was carried out in the Bay of Santa Ponça (Fig. 1), a small bay located on the southern coast of Mallorca (Balearic Islands). The bay is comprised of three beaches, two of which (Peguera and Santa Ponça) are located in semienclosed areas that experience recurrent summer phytoplankton blooms. Santa Ponça is a $~ 500 \mathrm{~m}$ long beach at the end of a westward facing embayment with an average depth of $5.5 \mathrm{~m}$. A shallow reef in about the middle of the embayment restricts the exchanges 

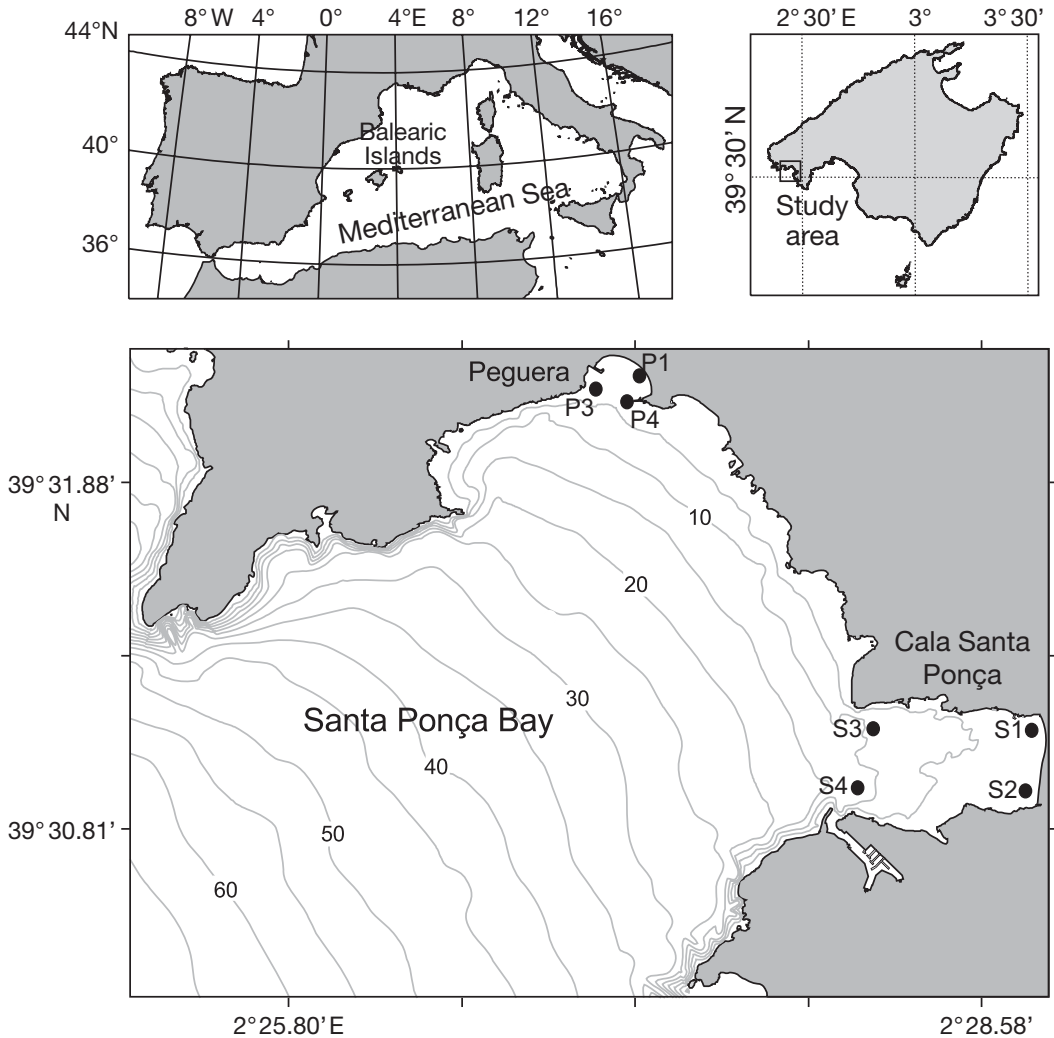

Fig. 1. Study area within the Western Mediterranean, including monitoring stations and coastal bathymetry (in metres). Stns P1, P2, S1 and S2 experience recurrent nearshore blooms, whereas $\mathrm{P} 3, \mathrm{~S} 3$ and S4 are indicative of coastal conditions

sample in a $50 \mathrm{ml}$ settling chamber and subsequent counting of cells within an appropriate area using a Leica-Leitz DM-IRB inverted microscope. Using this approach, the minimum species abundance detected was 20 cells $\mathrm{l}^{-1}$. Nutrient samples were frozen immediately after collection, and concentrations of nitrate, nitrite, ammonia, phosphate and silicate were measured with an autoanalyzer following Grassoff et al. (1983). For each sample, a $60 \mathrm{ml}$ subsample for the quantification of chlorophyll a (chl a) was filtered through $25 \mathrm{~mm}$ Whatman GF/F filters. Filters were then extracted in $8 \mathrm{ml}$ of $90 \%$ acetone, and concentrations of chl a were measured with a Turner Designs fluorometer.

Growth rates. In situ growth rate estimations were obtained from an experiment carried out during the summer of 2002 at Peguera, when a sustained dinoflagellate bloom was observed at this site. A detailed description of the bloom can be found in Basterretxea et al. (2004; see their 'Results' for development of the summer phytoplankton biomass). Net rates of change in dinoflagellate cell numbers in water samples incubated for $24 \mathrm{~h}$ under in situ conditions were used as a measure

with offshore coastal waters and reduces the total volume to $3.7 \times 10^{6} \mathrm{~m}^{3}$. Peguera is a crenulated beach $(\sim 300 \mathrm{~m})$ situated between a headland and a groin. Depths of up to $5 \mathrm{~m}$ are reached in the offshore side of an embayment, which has an approximate volume of $1.2 \times 10^{5} \mathrm{~m}^{3}$.

With the aim of characterizing the dinoflagellate outbreaks, both sites were monitored from May to September 2003. Samples were obtained at intervals of between 3 and 4 d at 3 stations at Peguera and 4 d at Santa Ponça. Stns P1, P2, S1 and S2 were representative of the nearshore environment, and P3, S3 and S4 provided information about the conditions at the entrance of the embayments (hereafter offshore stations). The abundance of dinoflagellate species, inorganic nutrient concentration, temperature and salinity were measured each time a water sample was withdrawn. Additionally, 2 temperature loggers recorded the temperature every half hour at a depth of $1.5 \mathrm{~m}$.

Samples $(150 \mathrm{ml})$ were fixed with lugol (1\% final concentration) for phytoplankton quantification. The general procedure for identifying and quantifying phytoplankton involved sedimentation (24 h) of a sub- of the net growth rates of dinoflagellates. A total of 38 experiments were carried out prior to and during the evolution of a massive Alexandrium taylori bloom. In each experiment, two 11 plastic cages were filled with a sample of water and submerged to a depth of $0.5 \mathrm{~m}$. All containers were pre-cleaned with $10 \% \mathrm{HCl}-$ Milli Q water and rinsed 3 times with distilled water. Initial and final subsamples were withdrawn from each cage for phytoplankton counts. Accurate data counts of the incubation samples were made, and species-specific net growth rates were estimated from changes in cell numbers according to Guillard (1973)

$$
\mu_{n}=\frac{1}{t_{2}-t_{1}} \ln \frac{N_{2}}{N_{1}}
$$

where $\mu_{n}$ is the net growth rate per day, and $N_{1}$ and $N_{2}$ are the initial cellular concentration and the average final cell concentration of the 2 incubations at $t_{1}$ and $t_{2}$.

Water renewal. Typical climate conditions in the Balearic Islands present a distinct seasonality with warm temperatures $\left(27^{\circ} \mathrm{C}\right.$ in August) and low rainfall during summer $(<26 \mathrm{~mm})$, resulting in little riverine input to the coast. In the absence of any significant sea 
level variations, coastal circulation in southern Mallorca is mainly regulated by wind forcing. Breeze conditions are prevalent for most of the summer, with intensities rarely exceeding $8 \mathrm{~m} \mathrm{~s}^{-1}$ (Ramis et al. 1990). This regime is occasionally disrupted by Tramontana episodes, a prevailing northerly wind with enhanced intensity. The combination of persistent shoreward directed seabreeze and an indented coastal geomorphology limits nearshore water exchange in the Balearic Islands during summer. Under these conditions current velocities at the entrance of the beaches are weak and temporally variable, following the diurnal wind patterns. Even during the wind-enhanced Tramontana episodes flushing is restricted, particularly along the southward facing coasts.

In order to investigate the effect of water renewal on HAB dynamics in Santa Ponça Bay, a conservative tracer method was used. For each area of interest, residence time was estimated from the tracks of neutrally buoyant particles in the flow, which were obtained from a 3D hydrodynamic numerical model following Monsen et al. (2002). If a water body with a volume $V$ and a flushing time $\tau$ is considered, the volumetric flow rate $q$ can be expressed as

$$
q=V / \tau
$$

In coastal waters $q$ is often unknown, and $\tau$ is calculated assuming that any introduction of mass into the water body is instantaneous and homogeneously mixed throughout the entire domain. Therefore, $\tau$ can be estimated from the evolution of a tracer over time, implying that mixing inside the water body is infinitely fast (e.g. Orfila et al. 2005). Assuming that the volume of the enclosed domain remains constant, the concentration $(C)$ of the tracer over time $(t)$ can be obtained from

$$
C(t)=C_{0} e^{-t / \tau}
$$

where $C_{0}$ is the tracer concentration at $t=0$. Flushing time can then be obtained by the least-square fit of the modeled particle evolution. A total of 27120 homogeneously distributed particles were released at Peguera, and 91200 at Santa Ponça, and allowed to drift for a period of up to $800 \mathrm{~h}$.

The algorithm selected for the hydrodynamic model was a linear, shallow-water, sigma-coordinate, 3D finite element model with spherical-polar extensions formulated in the frequency domain (FUNDY). The model solves the linearized 3D shallow-water equations, and is forced by tidal or other barotropic boundary conditions, wind and/or baroclinic pressure gradients. This numerical scheme was previously applied to evaluate the effect of local breezes on coastal circulation in previous studies of the area (see Werner et al. 1993). Estimations assume that conditions are at steady state and that wind represents the major forcing that controls water renewal.

Bloom dynamics. A simple 2-component model was used to analyse the role of water renewal on bloom development, whereby the population dynamics were described by a growth-loss-transport equation. The model, based in that of Steele \& Henderson (1992) and Truscott \& Brindley (1994), included logistic growth controlled by a carrying capacity term $(K)$ that allows for the absence of explicit tracking of nutrient concentration, which is convenient for the analysis of systems with undetermined input fluxes. Moreover, in this way, the uncertainties derived from parameters describing nutrient-uptake kinetics and/or shelf-shading effects are avoided. The form of the model is:

$$
\begin{aligned}
\frac{\mathrm{d} P}{\mathrm{~d} t} & =\mu P\left(1-\frac{P}{K}\right)-G_{\max } Z \frac{P^{2}}{k_{z}^{2}+P^{2}}-q P \\
\frac{\mathrm{d} Z}{\mathrm{~d} t} & =\gamma G_{\max } Z\left(\frac{P^{2}}{k_{z}^{2}+P^{2}}\right)-\left(m_{z}+q\right) Z
\end{aligned}
$$

where $P$ and $Z$ are phytoplankton and zooplankton concentrations respectively, $\mu$ is the specific growth rate for phytoplankton and $m_{z}$ is the specific loss rate of zooplankton. The model uses a Holling Type III grazing function, where $\gamma$ is the proportion of grazed phytoplankton that becomes new zooplankton biomass, $G_{\max }$ is the maximum grazing rate and $k_{z}$ is the half-saturation constant for grazing. In our case a flushing term $(q)$ was included to account for the water renewal rate, which represents an additional source of mortality for both $P$ and $Z$.

The model was forced using real temperature data and a simple analytical expression for the sinusoidal variation of photoperiod $(D)$, with a specific at summer solstice. Optimal temperature range $\left(T_{\text {opt }}\right)$ and photoperiod $\left(D_{\text {opt }}\right)$ were used solely to pulse growth from $\mu_{\min }$ to $\mu_{\max }$. In this study, the choice of parameters was based on available field data. The selected model currency is carbon, and the concentrations of $P$ and $Z$ are given in $\mathrm{g} \mathrm{C} \mathrm{m}^{-3}$ (see Table 1). For conversion between $\mathrm{C}$ and chl $\mathrm{a}$ we used a constant value for the C:chl $a$ ratio of 38, and time was measured in days (d). Estimates of $K$ were obtained by averaging the peak chlorophyll concentrations at the sampling site over the last $7 \mathrm{yr}$. The value for assimilation efficiency of zooplankton $(\gamma)$ is similar to the value of Fasham (1955), and the maximum grazing rate $\left(G_{\max }\right)$ is the same as that of Denman \& Peña (1999). The value for $m_{z}$ is in the range of that provided by Edwards \& Brindley (1999), but the half-saturation coefficient for zooplankton grazing $\left(k_{z}\right)$ is higher than the range provided by these authors $\left(0.02\right.$ to $\left.0.1 \mathrm{~g} \mathrm{C} \mathrm{m}^{-3}\right)$. In our case, values of $k_{z}$ that are higher than those in the oceanic system imply that zooplankton will adapt more slowly to the 
available food. We used this larger value on the basis that most microzooplankton species in the nearshore system (generally naked ciliates) are incapable of effectively grazing large bloom-forming phytoplankton cells; hence, a slower response is expected of these organisms when $P$ variations occur.

\section{RESULTS}

\section{Biological sampling}

During the summer of 2003, the coastal temperatures in the Balearics generally reached $\geq 26^{\circ} \mathrm{C}$, warming up to $29^{\circ} \mathrm{C}$ in July and occasionally exceeding $30^{\circ} \mathrm{C}$ in the nearshore environment. As shown in Fig. 2a, both Santa Ponça and Peguera exhibited the same temperature trend, and only minor variations were observed between them. Differences of up to $2^{\circ} \mathrm{C}$ were experi-
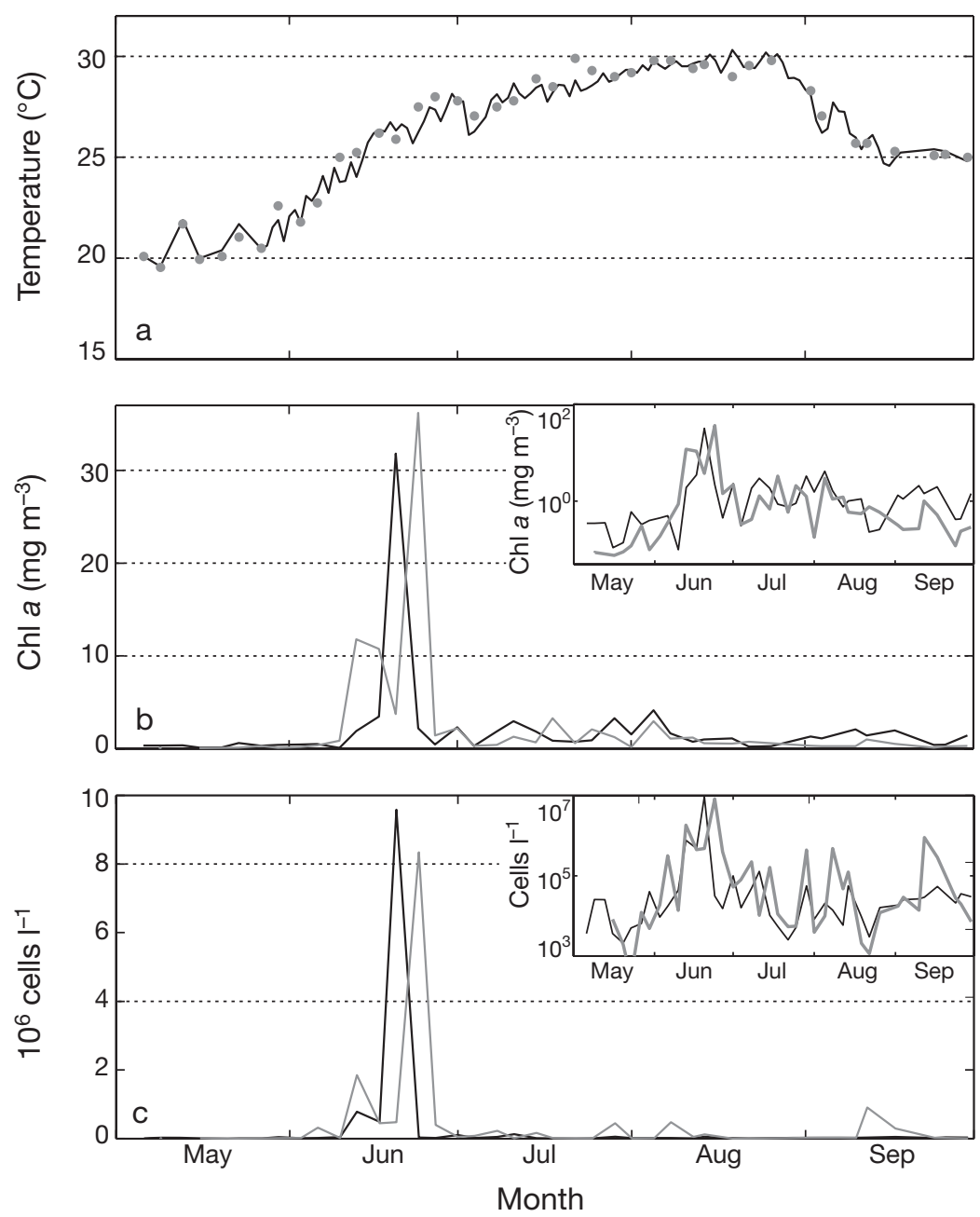

Fig. 2. Variations in (a) midday temperature (grey dots: Santa Ponça; black line: Peguera), (b) chl a and (c) total dinoflagellate cell abundance at Santa Ponça (grey) and Peguera (black). Insets: data in logarithmic form enced between nearshore (S1, S2 and P1) and offbeach stations (S3, S4, P3 and P4) (data not shown).

In keeping with the temperature profile, the nearshore (S1, S2 and P1) phytoplankton biomass (measured as chl a) followed a similar pattern at both sites. An extraordinary outbreak was observed in June (32 and $36 \mathrm{mg} \mathrm{m}^{-3}$ ), when the coastal water temperature increased from 21 to $26^{\circ} \mathrm{C}$ at an approximate rate of $1.2^{\circ} \mathrm{C}$ per week. Maximum cell abundances $(8 \times$

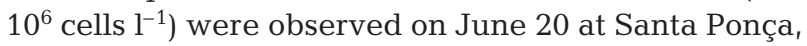

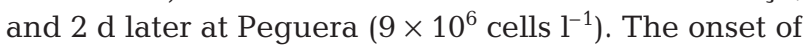
the bloom was marked by an increase of $\times 10^{2}$ cells $1^{-1}$ in $3 \mathrm{~d}$, and the episode extended over $3 \mathrm{wk}$. During the outbreak at Peguera, the microalgal population was comprised of Alexandrium taylori (64 to 94\%) and Gymnodinium sp. (species 1-CSIC) (1 to 35\%). The bloom species composition at Santa Ponça differed in that the species composition was more diverse. The most important co-blooming dinoflagellates were Gymnodinium spp., small dinoflagellates $(>15 \mu \mathrm{m})$ and Alexandrium spp. (A. taylori and A. minutum).

Total dinoflagellate cells in the nearshore presented values above $10^{4}$ cells $\mathrm{l}^{-1}$ for most of the summer. Fig. 3 reveals the differences in biomass and cell abundance between offshore and nearshore stations at both sampling sites. Summer offshore chlorophyll concentrations were almost invariably below $0.5 \mathrm{mg} \mathrm{m}^{-3}$ at both sites. In nearshore waters, low concentrations were observed on 44 and $35 \%$ of occasions at Peguera and Santa Ponça, respectively, whereas values of 1 to $1.5 \mathrm{mg} \mathrm{m}^{-3}$ were recorded in $>50 \%$ of samples. Thresholds in terms of abundance appear to be more diffuse. Modal values were in the order of $10^{3}$ cells $\mathrm{l}^{-1}$ in offshore waters and $10^{4}$ cells $\mathrm{l}^{-1}$ at nearshore stations. In $12 \%$ of the observations from Santa Ponça and 33\% from Peguera, cell abundances above $10^{4}$ cells $\mathrm{l}^{-1}$ were observed.

Inshore mean concentrations of dissolved inorganic nitrogen (DIN) exceeded 2.6 $\mu \mathrm{M}$ at Santa Ponça and 1.25 $\mu \mathrm{M}$ at Peguera over the sampling period, with respective maximum values reaching 19.0 and 2.4 $\mathrm{\mu M}$. Differences of up to $2 \mu \mathrm{M}$ were observed between average onshore and offshore concentrations at Santa Ponça, whereas intermediate DIN concentrations were recorded at Peguera, with no signifi- 


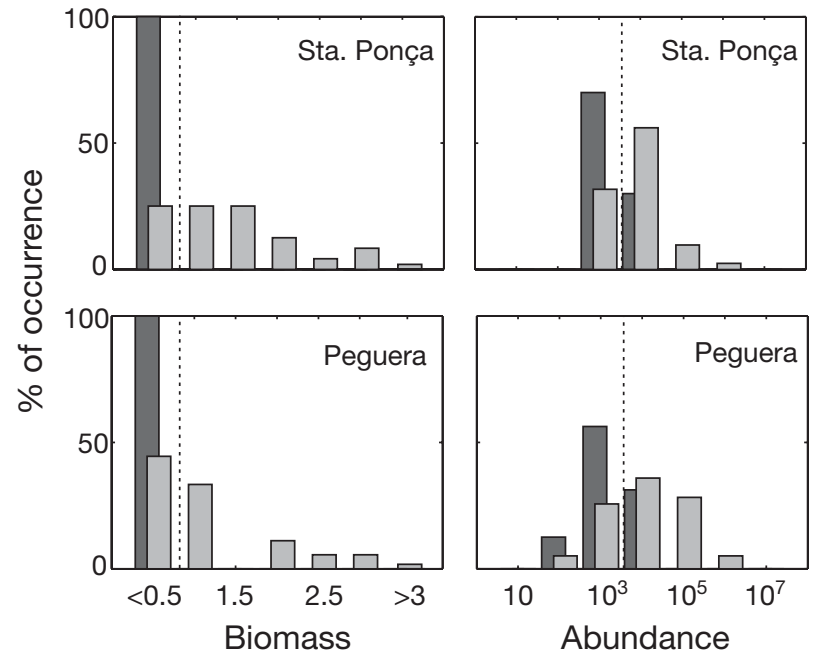

Fig. 3. Histograms of biomass ( $\mathrm{mg} \mathrm{chl} \mathrm{a} \mathrm{m} \mathrm{m}^{-3}$ ) and total cell abundance (cells ${ }^{-1}$ ) at Santa Ponça and Peguera at onshore (gray) and offshore (black) stations during the sampling period. Dashed lines: selected threshold values

cant differences among stations (Fig. 4). Phosphate occurred at lower concentrations (mean $=0.20 \pm$ $0.1 \mu \mathrm{M}$, $\max =4.5 \mu \mathrm{M})$, with onshore-offshore differences again being observed at Santa Ponça. Inorganic $\mathrm{N}: \mathrm{P}$ ratios varied between $8.4 \pm 3.7$ at Peguera and $18 \pm 9.1$ at Santa Ponça, with no significant onshore- offshore variation. Remarkably, these ratios are similar to those in groundwater (9 and 17 respectively), where inorganic nutrient concentrations are an order of magnitude higher.

In general, nutrient concentrations exhibited great temporal variability; consequently, no clear pattern or relationship could be discerned between the phytoplankton and the concentration of any nutrient. Furthermore, nutrient stoichiometry calculations for the bloom based on those of Justic et al. (1995) indicated very few cases of potential nutrient limitation of DIN or P-PO4 during the course of the phytoplankton bloom.

\section{Growth rates}

Estimated mean net growth rates for Alexandrium taylori during the pre-bloom stage were low, with values ranging between 0 and $0.32 \mathrm{~d}^{-1}$. This period extended from the beginning of the experiment to mid June, when dinoflagellate abundances where still bellow 2000 cells $\mathrm{l}^{-1}$. The experiments performed during the bloom period yielded markedly higher values $\left(0.71 \pm 0.6 \mathrm{~d}^{-1}, \mathrm{n}=31\right)$ and conspicuous day-to-day variability. Exceptional growth values above $2 \mathrm{~d}^{-1}$ were obtained at the end of July. Mean growth rates increased up to $0.9 \mathrm{~d}^{-1}$, when these outlying values were considered. The transition between these the 2 regimes is not well resolved; however, it is suggested that a progressive increase in growth rates occurs when temperature rises from 21.5 to $26^{\circ} \mathrm{C}$ in June (Fig. 5).
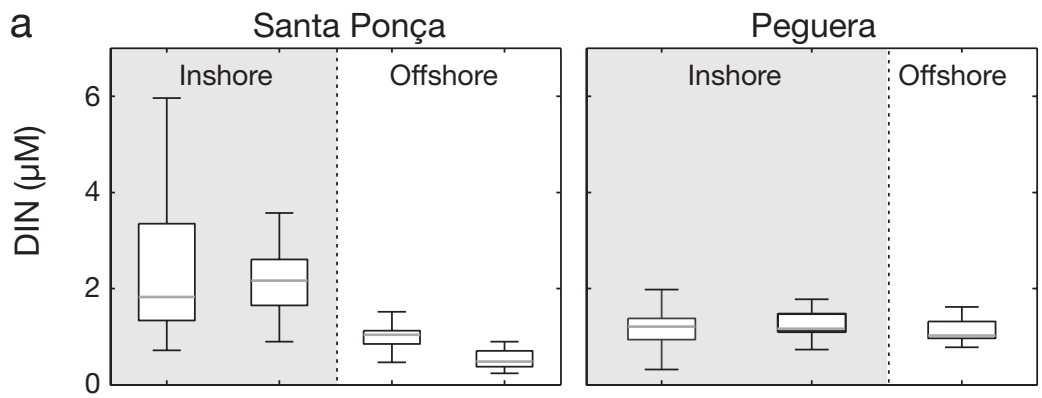

b

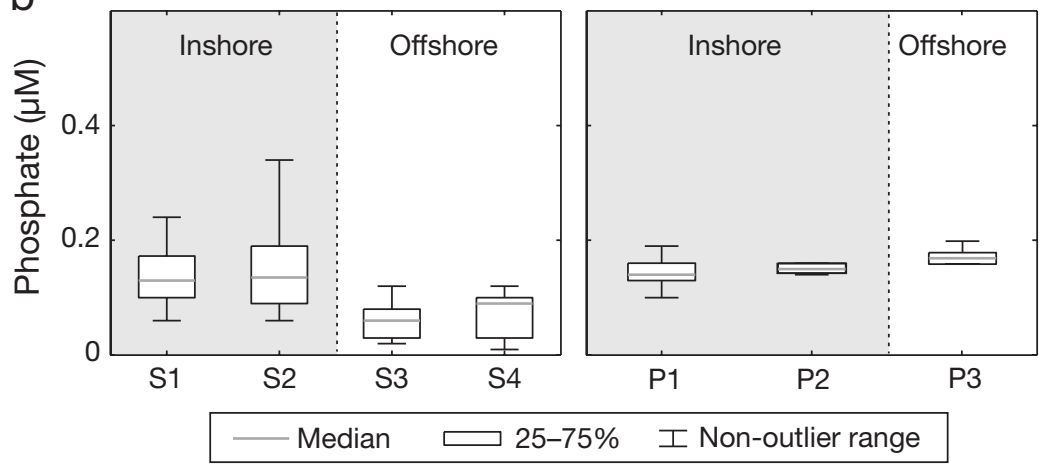

Fig. 4. Boxplot of (a) dissolved inorganic nitrogen (DIN) and (b) phosphate concentration at inshore and offshore stations in each embayment

\section{Water renewal}

Tracer analysis under breeze conditions reveals that $50 \%$ of the particles released at Santa Ponça remained in the domain after $15 \mathrm{~d}$, whereas renewal occurred more rapidly at Peguera (50\% remained after $\sim 3 \mathrm{~d}$ ). Exponential fitting of the particle evolution yields $\tau$ values of 19.3 and $13.6 \mathrm{~d}$, respectively, under breeze conditions, decreasing to 4.2 and 3.8 d under Tramontana episodes. Nevertheless, as shown in Fig. 6, exponential fits tend to underestimate residence time in the case of Tramontana winds. Moreover, in the case of Peguera a few particles $(20 \%)$ remain trapped under seabreeze forcing, yielding an asymptotic behavior. Differences among beaches are related to differences in volume between both embay- 


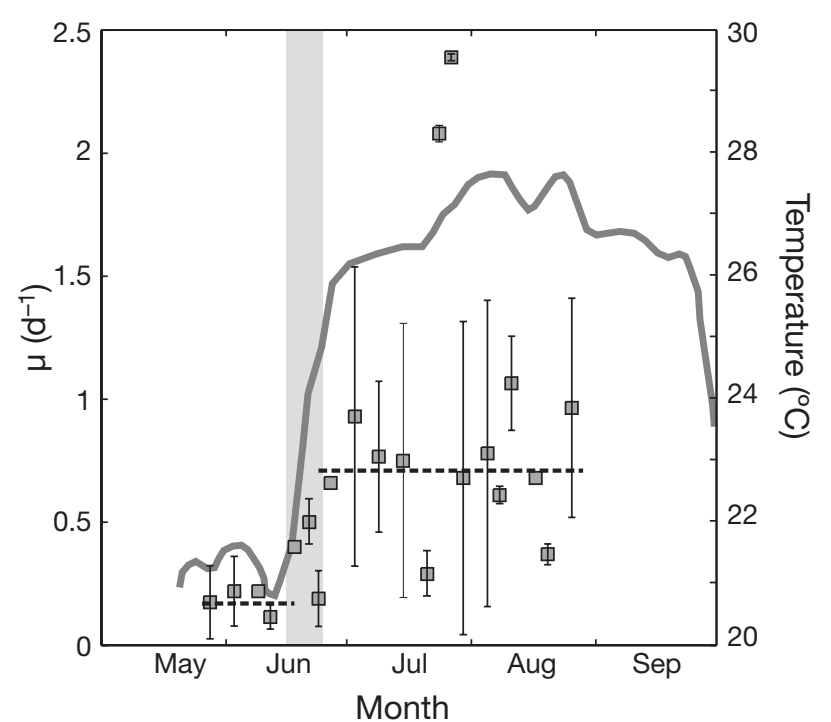

Fig. 5. Alexandrium taylori. Mean net growth rate $(\mu)$ obtained from incubation experiments at Peguera in 2002, and corresponding lowpass filtered water temperature (grey line). Each point represents 3 incubation experiments. Dashed lines: mean values used for modeling. Grey bar: transition from low to high growth rates during rapid water temperature warming

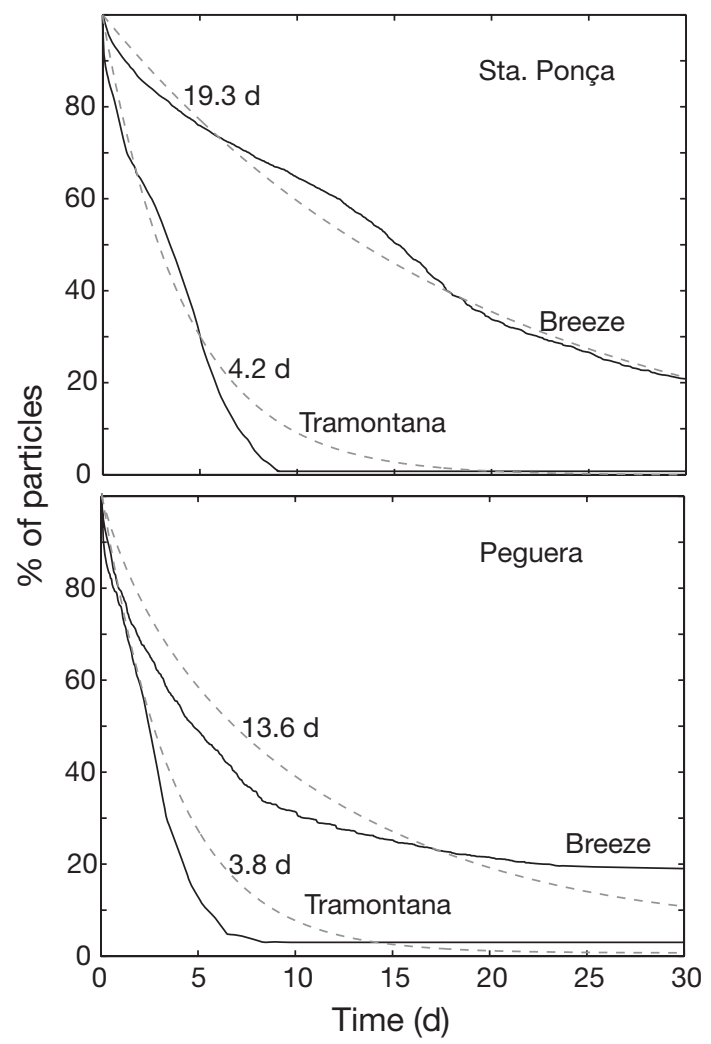

Fig. 6. Simulated temporal evolution of tracers remaining at Santa Ponça and Peguera (solid lines), and adjustment leading to water renewal estimates (dashed lines). Specified time points: $\tau$ in the exponential fit of Eq. (3), where $C_{0}$ is the initial concentration of the particles, expressed as \% ments, and the resultant $q$ for breeze conditions is comparable in both cases $\left(q=0.052 \mathrm{~d}^{-1}\right.$ for Santa Ponça and $0.073 \mathrm{~d}^{-1}$ for Peguera). Under real fluctuating conditions (year cycle) $q$ is somewhat higher $(0.090 \pm 0.08$ and $0.15 \pm 0.08 \mathrm{~d}^{-1}$ respectively), but is still indicative of slow water renewal at both beaches.

Amongst the different factors that influence water renewal, wind direction is probably the most relevant. As shown in Fig. 7, wind patterns included a similar bimodal behavior at both locations, with higher $q$ for winds blowing from $\mathrm{N}$ to $\mathrm{SE}$ and markedly reduced values of $q$ for other directions. Nonetheless, it should be noted that wind events favoring enhanced renewal were scarce and episodic during the summer season.

\section{Bloom dynamics}

As shown by Truscott (1995), the behaviour of a $P Z$ system can be explained from the perspective of the excitability of phytoplankton, i.e. the capability for this population to be subject to rapid changes. The stability of the final steady state of $P$ and $Z$ is governed by the gradient $\mathrm{d} Z / \mathrm{d} P$ of the non-dimensionalized equations for $P$ and $Z$. Briefly, if $\mathrm{d} Z / \mathrm{d} P<0$ then the equilibrium point is a stable point, whereas if $\mathrm{d} Z / \mathrm{d} P>0$ then it is an unstable node, and the stable solution is a limit cycle. As depicted in Fig. 8 this changes at points $\left(P_{\min }, Z_{\min }\right)$ and $\left(P_{\max }, Z_{\max }\right)$. When $P_{\min }>P>P_{\max }$, the equilibrium of the system is unstable and a limit cycle is developed. The region of excitability is indicated by the ' $\mathrm{S}$ ' shape of the curve and, as shown in Fig. 8, this decreases with increasing $q$. In our case, the sigmoid shape of the curve is only preserved for

$$
0<v<\frac{1}{3 \sqrt{3}} \frac{\mu}{\mu+q}
$$

where $v=\frac{k_{z}}{K}$.

Evidently, this solution becomes that of Truscott (1995) $\frac{1}{3 \sqrt{3}}$ when $q=0$.

For the parameters provided in Table 1 the excitability condition is accomplished for values of $q<0.04 \mathrm{~d}^{-1}$ when $\mu=\mu_{\min }$, and for $q<0.18$ when $\mu=\mu_{\max }$.

Typical conditions for uncoupling between $P$ and $Z$ occur when $\mu$ increases to $\mu_{\max }$ in response to light, temperature, nutrients or other factors that influence phytoplankton growth. Following the description above, 3 scenarios can be anticipated depending on the $\mathrm{d} Z / \mathrm{d} P$ ratio. If $\mathrm{d} Z / \mathrm{d} P$ is always negative, then the evolution of the system generates a stable bloom (same shape independent of $\mu_{\max }$ ) where population is con- 

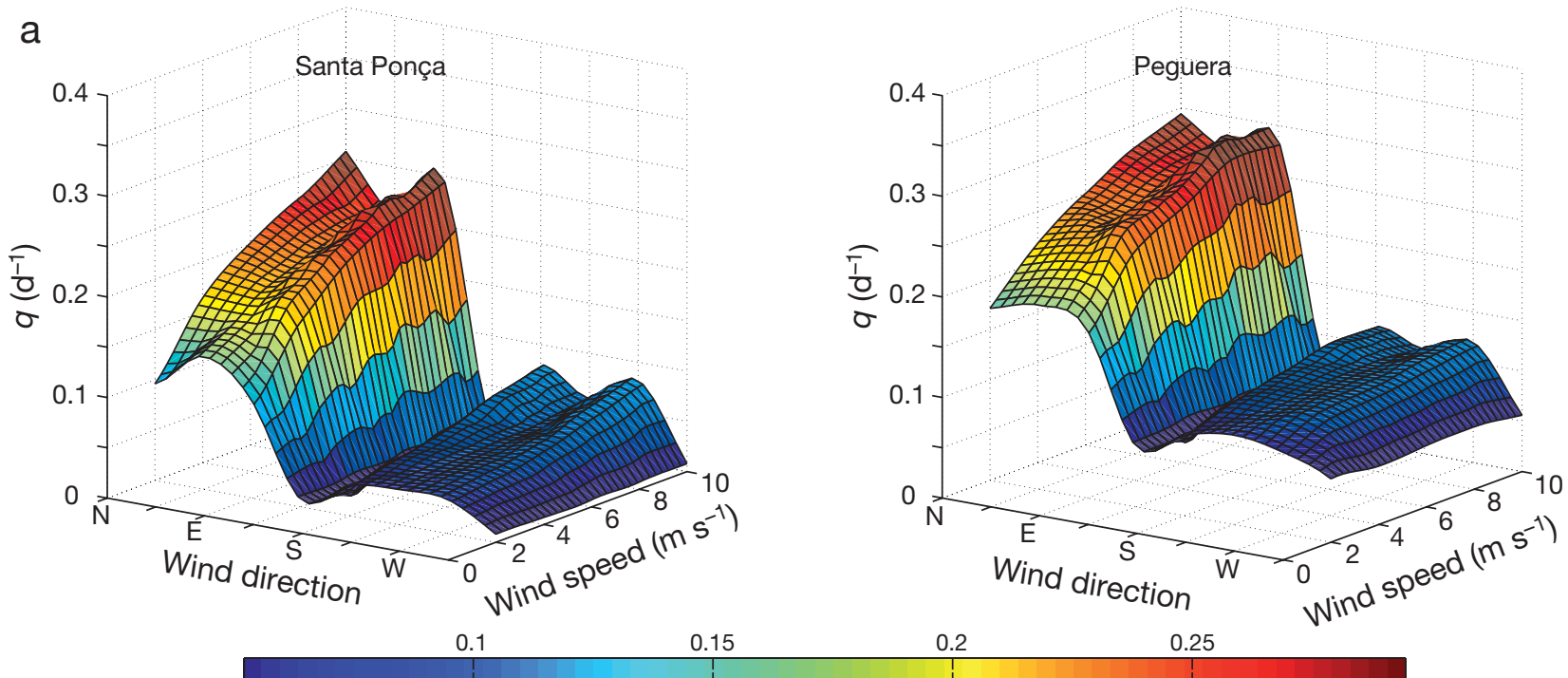

b

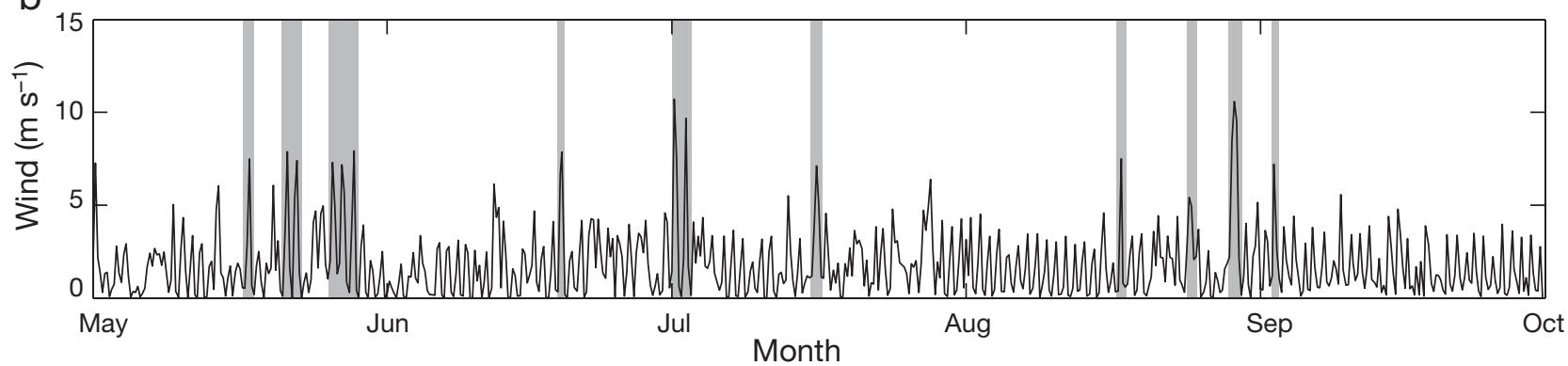

Fig. 7. Calculated flushing rate for Santa Ponça and Peguera under different (a) wind forcing, and (b) wind recorded at Santa Ponça. Grey stripes: Tramontana episodes. Sacle bar in (a) shows the volumetric flow rate $(q) \mathrm{d}^{-1}$

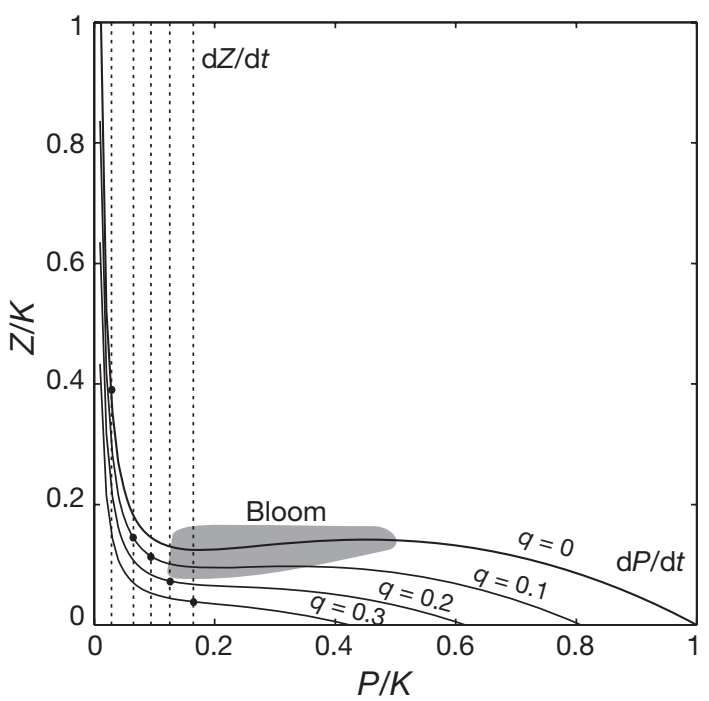

Fig. 8. Schematic diagram of nullclines for the phytoplanktonzooplankton $(P Z)$ system using different flushing rates $(\mu=$ $\left.\mu_{\max }\right)$. Solid lines: $\mathrm{d} P / \mathrm{d} t=0$ (null cline); dashed lines: $\mathrm{d} Z / \mathrm{d} t=$ 0 ; grey patch: area in which the sigmoidal shape of the curve is preserved for different $q$ values trolled by grazing. Conversely, if $\mathrm{d} Z / \mathrm{d} P$ is always positive, then the phytoplankton population is relatively uncontrolled and expands to a high density situation that is controlled by $\mu_{\max }$. Our case represents an intermediate situation whereby the variation from $\mu_{\min }$ to $\mu_{\max }$ forces a change from $\mathrm{d} Z / \mathrm{d} P>0$ to $\mathrm{d} Z / \mathrm{d} P<0$ (assuming low $q$ values); once the bloom is triggered, the behaviour of the system is controlled by the variations of $\mu$ and $q$. As displayed in Fig. 9, under these circumstances the model is able to reasonably reproduce the bloom in both embayments using values within the range of those observed in field experiments. Gross cell growth rates in the model were approximated by measured net rates in the belief that they are representative of the lower threshold of phytoplankton growth.

Fig. 10a reveals how the variation in the shape of the bloom is influenced by the increase in $\mu_{\max }$. The system shows little sensitivity for $\mu_{\max }>0.52 \mathrm{~d}^{-1}$ : only the slope of the bloom initiation increases with increasing $\mu_{\max }$. Conversely, lower values produce delayed biomass peaks, but the system asymptotically tends to a shape determined both by the carrying capacity of the system 
Table 1. Variables and parameters used in simulations (unless otherwise noted) and their definitions

\begin{tabular}{|c|c|c|c|}
\hline Parameter & Description & Value & Unit \\
\hline$C$ & Tracer concentration & - & $\%$ \\
\hline$C_{0}$ & Initial tracer concentration & 100 & $\%$ \\
\hline$D_{\text {opt }}$ & Optimal photoperiod & $>0.60$ & $\mathrm{~d}$ \\
\hline$G_{\max }$ & Maximum grazing rate & 1 & $\mathrm{~d}^{-1}$ \\
\hline$k_{z}$ & Half-saturation constant for grazing & 0.17 & $\mathrm{~g} \mathrm{C} \mathrm{m}^{-3}$ \\
\hline$K$ & Carrying capacity & 1.2 & $\mathrm{~g} \mathrm{C} \mathrm{m}^{-3}$ \\
\hline$\mu$ & Specific growth rate for $\mathrm{P}$ & - & $\mathrm{d}^{-1}$ \\
\hline$\mu_{\min }$ & Growth rate of $\mathrm{P}$ at pre-bloom phase & 0.12 & $d^{-1}$ \\
\hline$\mu_{\max }$ & Growth rate for $\mathrm{P}$ during bloom conditions & is 0.52 & $\mathrm{~d}^{-1}$ \\
\hline$m_{z}$ & Zooplankton mortality rate & 0.03 & $\mathrm{~d}^{-1}$ \\
\hline$P$ & Phytoplankton biomass & - & $\mathrm{g} \mathrm{C} \mathrm{m}^{-3}$ \\
\hline$q$ & Flushing rate & $0-0.5$ & $\mathrm{~d}^{-1}$ \\
\hline$T_{\text {opt }}$ & Optimal temperature range & $22-28$ & ${ }^{\circ} \mathrm{C}$ \\
\hline$\gamma$ & Zooplankton assimilation efficiency & 0.75 & dimensionless \\
\hline$V$ & Embayment volume & See text ${ }^{a}$ & $\mathrm{~m}^{-3}$ \\
\hline$Z$ & Zooplankton biomass & - & $\mathrm{g} \mathrm{C} \mathrm{m}^{-3}$ \\
\hline
\end{tabular}
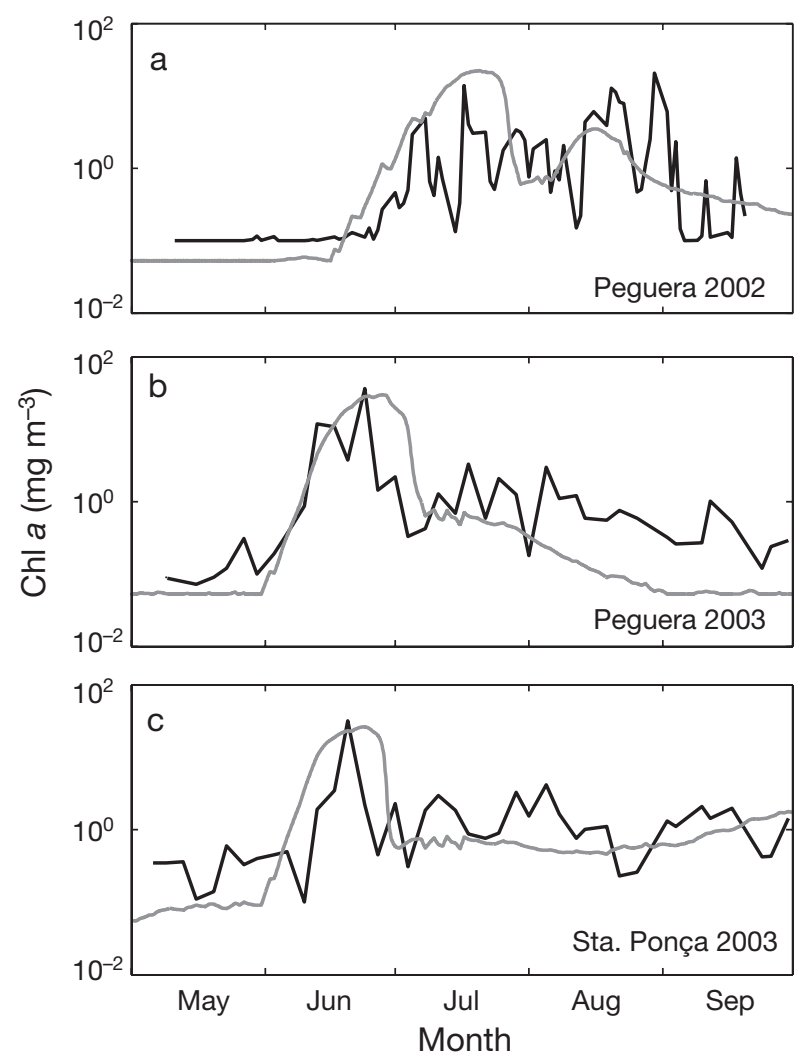

Fig. 9. Measured phytoplankton biomass (black line) and simulated results (grey line). Simulations were performed using daily flushing rates calculated from average wind conditions for each day

and by grazing control. As shown in Fig. 10b, the length of the optimal growth period also influences the evolution of the bloom. Short $\mu_{\max }$ conditions, resulting either because temperature is above or below $T_{\text {opt }}$ generate reduced biomass peaks that progressively decay without triggering significant zooplankton responses. Sustained blooms with repeated oscillations, similar to that observed at Peguera in 2002, are explained by persistent $T_{\text {opt }}$ conditions. Similarly, stagnant conditions generate relatively stable high biomass equilibria where the shift in $\mu_{\max }$ is relatively unimportant. Increased flushing rates weaken the peak and reduce bloom persistence. Fig 10d depicts the response of the system to changes in $v$. For lower values (i.e. 0.05) the system presents excitability for any $q$ within the range of values considered (the excitability is lost for $q>1.5 \mathrm{~d}^{-1}$ ) and a bloom following the $\mathrm{p}$-cline will occur $(\mathrm{d} Z / \mathrm{d} P$ always negative). This is the evolution described by Truscott (1995), whereby $q$ has no effect. Conversely, for high $v$ values $(\mathrm{d} Z / \mathrm{d} P$ always positive), the system is always at a state beyond the excitabity region and is thus entirely regulated by variations in $\mu_{\max }$. The slope of the curve at the bloom onset is regulated by $\mu_{\max }$, whereas the senescence is controlled by $\mu_{\min }$.

\section{DISCUSSION}

Anthropogenically enriched coastal areas of the Mediterranean provide a unique environment for phytoplankton growth. These sites are prone to suffer from proliferations not only because inorganic nutrients are high when compared with offshore conditions, but also because the organic compounds are abundant, comprising a variable amount of between 50 and $80 \%$ of $\mathrm{N}$ and P pools (e.g. Lucea et al. 2003). For most of the year, physical factors (photoperiod, irradiance, mixing, temperature, stratification etc.) have a limiting influence on dinoflagellate proliferation; thus, even in times of enhanced allochthonous nutrient input along the coast, blooms are rare. With the onset of summer conditions (between May and June), flagellate outbursts become a growing economic and environmental problem. Calm conditions with less wind are regarded as ideal for biomass accumulation in the nearshore. In this study, we presented evidence of simultaneous blooms comprised of different dinoflagellate assemblages at 2 nearby locations: Peguera and Santa Ponça. Even though these proliferations tend to be almost monospecific, blooms of different species may still develop if favorable conditions occur (as shown). This is suggestive of some sort of non-species-specific syn- 


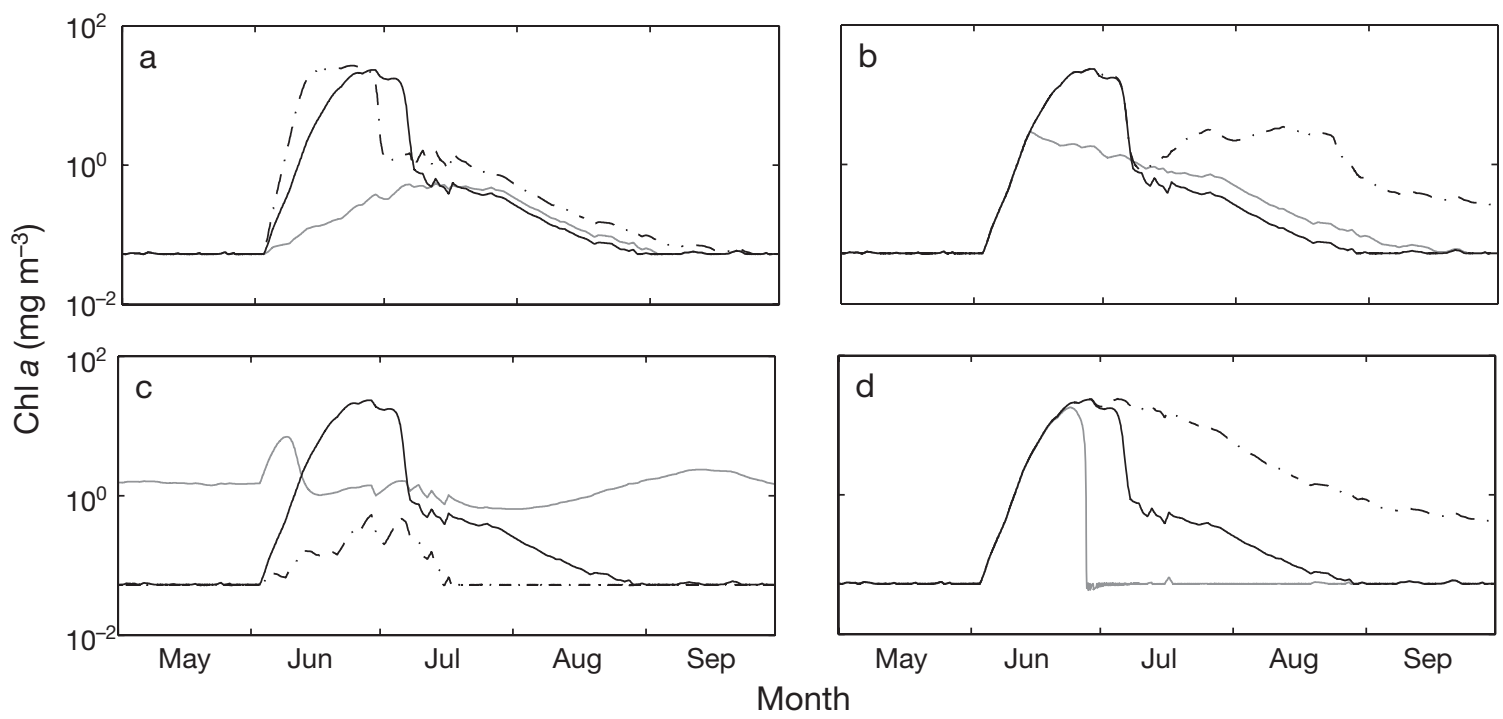

Fig. 10. Numerical simulations of (a) growth rates $\left(\mu_{\max }=0.31,0.71,1.11\right)$, (b) optimal growth temperature range $\left(T_{\mathrm{opt}}=23-25\right.$, $23-28,23-31)$, (c) flow rates $(q \times 0.3,1,3)$ and (d) $k_{z} / K(0.05,0.14,0.5)$. Grey lines: first case; solid black lines: second case; dot-dash lines: third case. Simulations were performed using daily flushing rates calculated from average wind conditions for each day

chronization in the mechanisms that lead to the triggering of blooms within both systems.

Raimbault et al. (1988) showed that in the Mediterranean, the composition of small-sized background phytoplankton remained relatively stable during blooms when biomass increased beyond $0.5 \mathrm{mg} \mathrm{m}^{-3}$, and that above this density the blooms started to be dominated by larger organisms. Although intended for a spring bloom, this concept appears to be consistent with the differences observed between inshore and offshore communities during the bloom. Large dinoflagellates like Alexandrium spp. and Gymnodinium spp. increase in terms of growth and accumulation, whereas smaller phytoplankton (similar to those offshore) remain relatively stable. A similar pattern was reported by Bec et al. (2005) for a Mediterranean lagoon subjected to summer diatom blooms: they suggested that the observed enhanced growth rates of the large population fraction $(>2 \mu \mathrm{m})$ may rely on new rather than recycled nutrients. Shifts in the dominance of the different size fractions under the influence of variable external nitrogen sources is supported by species competition experiments (see Hecky \& Kilham 1988) and food-web structure modeling studies, which predict increases in the overall size of the planktonic community in response to increases in the nutrient content in the system (Armstrong 1994, Kemp et al. 2001). Nutrient enhancement is reported to produce an exponential decline in the ratio of picophytoplankton to total phytoplankton biomass and primary production at nitrogen concentrations of $>1 \mu \mathrm{M}$ (Agawin et al. $2000)$, thus favoring proliferation of larger species.
Nevertheless, the tendency for change in size structure is not a ubiquitous feature of the Mediterranean coastal communities. For example, Vidal \& Duarte (2000) reported a low-biomass response to increased nutrient loading on the coast of Blanes (northeast Spain). Furthermore, some evidence suggests that the relationship exists between cell size, growth rate and growing conditions, not between cell size and nutrient levels (Irigoien et al. 2005).

We have proposed a simple $P Z$ model intended to reproduce the dominant dynamics and provide analytical criteria for coastal bloom occurrence. A general implication of our study is that nearshore phytoplankton blooms are generated by changes in cell growth that destabilize the $P Z$ trophic link, and that the evolution of the system is modulated by the concomitant variations in physical forcing. Departing from a positive, stable equilibrium - in which the low phytoplankton growth rates are balanced by biological losses and transport-endogenous and exogenous changes resulting in significant variation in $\mu$ determine a new state for the system, manifested either as an episodic outbreak or a more persistent phytoplankton biomass enhancement. Freund et al. (2006) stated that the uncoupling between the phytoplankton bloom and the zooplankton response is rooted, among other reasons, in the separation of time scales expressed by the numerical values of the parameters $m_{z}$ and $\gamma G_{\max }$ which are smaller than the parameters $\mu$ and $G_{\max }$. Differences in water renewal modulate the shape of the bloom as determined by the growth rates, and also exacerbate the effects caused by the slower response 
of zooplankton. Regarding water renewal, it should be noted that owing to their semi-enclosed nature, it is not only wind intensity but also wind direction that is a determinant of the regulation of water exchange in the analyzed embayments. In this sense, the geographical orientation of the coast and its relationship with the direction of prevailing winds is an intrinsic characteristic that may be relevant to outbreak occurrence.

As shown in Fig. 10c, high flushing rates reduce system excitability and cell accumulation; consequently, generalized alongshore blooms are only observed under persistent calm weather conditions. In the unlikely situation of continuously high water renewal, the system is basically regulated by the equilibrium between growth and water renewal and the role of zooplankton becomes secondary. This situation is not well described by a $P Z$ model because important advection possibly conveys strong changes in the carrying capacity of the system. In our case, $K$ was considered to be a constant selected on the basis of observed maximum phytoplankton biomass in these waters, but as demonstrated in the analysis of $v$, it plays an important role in setting the threshold for the excitability of the system. Empirical evidence shows that cell abundances above $10^{7}$ cells $\mathrm{l}^{-1}$ are rare, but this threshold includes processes of distinct nature (either physical, chemical or biological). Generally, the effect of a variable $K$ depends on the rate of change, because an additional timescale that interacts with the biological timescales considered in the model is introduced. If $K$ varies slowly in comparison with the biological processes, the evolution of the system will asymptotically adapt to these variations. If, conversely, a rapid variation is considered, the system will behave by following the average values (the same is valid for $\mu$ ). A more critical behavior could be expected from coherent variations of $K$ and other parameters, or at some stages of the bloom (i.e. when a change from $\mu_{\min }$ to $\mu_{\max }$ is forced).

Evidence reveals that owing to their higher compensation intensities, some dinoflagellate species appear to be more competitively suited for growth under the high summer irradiances experienced in the Mediterranean (e.g. Smayda 1997). In our case, the observed rate of chlorophyll increase during the bloom onset required sustained growth rates above $0.5 \mathrm{~d}^{-1}$, which is consistent with the measured growth rates and with published in situ growth rates of single cells of Alexandrium taylori at other sites (Garcés et al. 1998, 2005). Nonetheless, daily growth rates of some species can greatly exceed this value for short periods (i.e. up to $3.54 \mathrm{~d}^{-1}$, Smayda 1997), and HAB species do not typically exhibit sustained growth rates higher than those of other phytoplankton. For example, reported in situ growth rates of dinoflagellates are generally below $<1.0 \mathrm{~d}^{-1}$ (Stolte \& Garcés 2006).
As shown by the modeling results, it is the change in $\mu$ between the pre-bloom and bloom stages that is relevant to the forcing of the system. Various external and/or internal factors have been proposed in attempts to explain changes in growth rates in phytoplankton populations. (1) Intraspecific genetic variability changes over time within the same population are possible (Orsini et al. 2002). This suggests that only a fraction of the resident population is responsible for the bloom. Furthermore, differences among growth rates of the different strains are possible. (2) Excretion of chemical signals produced by the organisms could be responsible for the different physiology. Hastings \& Greenberg (1999) suggested that the so-called 'quorum sensing' hypothesis, which relates to the chemical signals produced by an organism, occurs in bacterial populations. Although this effect has not been documented for phytoplankton, it is known that cell inoculum in batch cultures requires cell filtrates from older cultures to initiate active growth (Fogg 1987). (3) More attention has been devoted to the effect of environmental factors (such as irradiance, nutrients, turbulence, vitamins and, particularly, temperature) on growth (Guillard 1973 and references therein). Temperature is known to alter the enzymatically regulated processes of most organisms, and hence should not be disregarded as a triggering factor of the previously mentioned mechanisms. Indeed, seasonal temperature variations are known to play a major role in the regulation of growth rates of coastal communities of the Mediterranean (e.g. Agawin et al. 1998). Most phytoplankton species have an optimal temperature for growth. A temperature range of 22 to $28^{\circ} \mathrm{C}$ was used in our simulations, in which no remarkable change in environmental conditions between the pre-bloom and bloom period was observed (with the exception of the seasonal warming). Obviously, temperature variations do not explain the observed day-to-day variability within each bloom phase, and other mechanisms should be considered to account for this short term variability.

Another possible explanation for unbalanced growth is relief from grazing control. Grazing rates are relevant not only to the control of the biomass, but also at the initial stages of the outbreak (Uye \& Takamatsu 1990). Planktonic macrograzers, capable of ingesting large-sized cells, are scarce in the coastal environment (Calbet et al. 2001), and thus presumably relegated to a minor role. In the case of microzooplankton, they would mainly control variations of smaller-sized cells. Only organisms such as rotifers and heterotrophic protists have comparable growth rates and may hence co-bloom. Moreover, it is well known that some bloom-forming phytoplankton species exhibit ecological and physiological characteristics that either reduce zooplankton feeding rates or 
hamper egg production and thus population growth (e.g. Turner 2006). Although the reduction of topdown control in microalgal proliferations is situationspecific, the blooming species constitute a parallel foodweb pathway that is basically modulated by physical and endogenous factors.

Model performance is lower when these biological loss terms become important. Edwards \& Yool (2002) demonstrated that the selection of the higher predation closure term can strongly influence model dynamics. In a $P Z$ model, high zooplankton biomass increases phytoplankton losses, accelerating the bloom outcome. However, the senescence phase in itself could well be inevitable in either the presence or absence of zooplankton. Other factors of phytoplankton mortality, such as population ageing, encystment, infection, species succession or factors not accounted for in the model, could play a role in the fate of the bloom. Indeed, evidence reveals that algal evolution substantially alters predator-prey dynamics (Yoshida et al. 2003). Uncertainties at this stage of the bloom - in which cell biology and population life history may be important - appear to be greater, and possibly require more sophisticated modelling approaches.

Acknowledgements. This study was partially supported by the EU-financed research projects STRATEGY (EVK·CT 2001 00046), SEED (GOCE-003875) and THRESHOLDS (IP003933). We are indebted to Calviá Town Hall, and especially to E. Cozar, for collaborating and facilitating fieldwork. We also thank B. Casas for assistance with field work and R. Ventosa for nutrient analyses. E.G. was supported by a Ramon y Cajal contract from the Spanish Ministry of Science and Education, and A.J. by a MCYT postdoctoral fellowship.

\section{LITERATURE CITED}

Agawin NSR, Duarte CM, Agustí S (1998) Growth and abundance of Synechococcus sp. in a Mediterranean Bay: seasonality and relationship with temperature. Mar Ecol Prog Ser 170:45-53

Agawin NSR, Duarte CM, Agustí S (2000) Nutrient and temperature control of the contribution of picoplankton to phytoplankton biomass and production. Limnol Oceanogr 45:591-600

Armstrong RA (1994) Grazing limitation and nutrient limitation in marine ecosystems: steady-state solutions of an ecosystem model with multiple food chains. Limnol Oceanogr 39:597-608

Basterretxea G, Garcés E, Jordi A, Masó M, Tintoré J (2004) Breeze as Alexandrium taylori bloom favoring mechanism in a Mediterranean pocket beach. Estuar Coast Shelf Sci 32:1-12

Bec B, Husseini-Ratrema J, Collos Y, Souchu P, Vaquer A (2005) Phytoplankton seasonal dynamics in a Mediterranean coastal lagoon: emphasis on the picoeukaryote community. J Plankton Res 27:881-894

Calbet A, Garrido S, Saiz E, Alcaraz M, Duarte CM (2001) Annual zooplankton succession in coastal NW Mediterranean waters: the importance of the smaller size fractions. J Plankton Res 23:319-331
Cartensen C, Conley DJ, Henriksen P (2004) Frequency, composition and causes of summer phytoplankton blooms in a shallow coastal ecosystem, the Kattegat. Limnol Oceanogr 49:190-201

Collos Y, Gagne C, Laabir M, Vaquer A, Cecchi P, Souchu P (2004) Nitrogenous nutrition of Alexandrium catenella (Dinophyceae) in cultures and in Thau Lagoon, Southern France. J Phycol 40:96-103

Denman KL, Peña MA (1999) A coupled 1-D biological/physical model of the northeast subarctic Pacific Ocean with iron limitation. Deep-Sea Res II 46:2877-2908

Duarte CM, Agustí S, Agawin NSR (2000) Response of a Mediterranean phytoplankton community to increased nutrient inputs: a mesocosm experiment. Mar Ecol Prog Ser 195:61-70

Edwards AM, Brindley J (1999) Zooplankton mortality and the dynamical behaviour of plankton population models. Bull Math Biol 61:303-339

Edwards AM, Yool A (2000) The role of higher predation in plankton population models. J Plankton Res 22:1085-1112

Fasham MJR (1995) Variations in the seasonal cycle of biological production in subarctic oceans: a model sensitivity analysis. Deep-Sea Res 42:114-1149

Figueiras FG, Pitcher GC, Estrada M (2006) Harmful algal bloom dynamics in relation to physical processes. In: Graneli E, Turner J (eds) Ecology of harmful algae, Vol 189. Springer-Verlag, Berlin, p 127-138

Fogg GE (1987) Algal cultures and phytoplankton ecology. University of Wisconsin Press, Madison, WI

Franks P (1997) Models of harmful algal blooms. Limnol Oceanogr 42:1273-1282

Freund JA, Mieruch S, Scholze B, Wiltshire K, Feudel U (2006) Bloom dynamics in a seasonally forced phytoplankton zooplankton model. Trigger mechanisms and timing effects. Ecol Complex 3:129-139

Garcés E, Delgado M, Masó M, Camp J (1998) Life history and in situ growth rates of Alexandrium taylori (Dinophyceae, Pyrrophyta). J Phycol 34:880-887

Garcés E, Vila M, Masó M, Sampedro N, Giacobbe MG, Penna A (2005) Taxon-specific analysis of growth and mortality rates of harmful dinoflagellates during bloom conditions. Mar Ecol Prog Ser 301:67-79

Garcés E, Fernandez M, Penna A, Lenning KV, Gutierrez A, Camp J, Zapata M (2006) Characterization of NV Mediterranean Karlodinium spp. (Dinophyceae) strains using morphological, molecular, chemical and physiological methodologies. J Phycol 42:1096-1112

Grasshoff K, Ehrhardt M, Kremling K (1983) Methods of sea water analysis. Verlag Chemie, Weinheim

Guillard RRL (1973) Division rates. In: Stein JR (ed) Handbook of phycological methods: culture methods and growth measurements, Vol 1. Cambridge University Press, New York, p 289-312

Hastings JW, Greenberg EP (1999) Quorum sensing: the explanation of a curious phenomenon reveals a common characteristic of bacteria. J Bacteriol 181:2667-2668

Hecky RE, Kilham P (1988) Nutrient limitation of phytoplankton in freshwater and marine ecosystems: a review of recent evidence on the effects of enrichment. Limnol Oceanogr 33:796-822

Hodgkiss IJ, Ho KC (1997) Are changes in N:P ratios in coastal waters the key to increased red tide blooms? Hydrobiologia 352:141-147

Irigoien X, Flynn KJ, Harris RP (2005) Phytoplankton blooms: a 'loophole' in microzooplankton grazing impact? J Plankton Res 27:313-321

Jansá JJ (1994) Variación anual e interanual de los factores 
fisicoquímico-biológicos generales del medio pelágico de la Bahía de Palma (Islas Baleares, España) desde mayo de 1988 hata mayo de 1992. Ministerio de Agricultura, Pesca y Alimentación, Madrid

Justic D, Rabalais NN, Turner RE, Dortch Q (1995) Changes in nutrient structure of river-dominated coastal waters: stoichimetric nutrient balance and its consequences. Estuar Coast Shelf Sci 40:339-356

Kemp WM, Brooks MT, Hood RR (2001) Nutrient enrichment, habitat variability and trophic transfer efficiency in simple models of pelagic ecosystems. Mar Ecol Prog Ser 223: $73-87$

Lopez-Flores R, Garcés E, Boix D, Badosa A, Brucet S, Masó M, Quintana XD (2006) Comparative composition and dynamics of harmful dinoflagellates in Mediterranean salt marshes and nearby external marine waters. Harmful Algae 5:637-648

Lucea A, Duarte CM, Agusti S, Sondergaard M (2003) Nutrient (N, P and $\mathrm{Si}$ ) and carbon partitioning in the stratified NW Mediterranean. J Sea Res 49:157-170

Monsen NE, Cloern JE, Lucas LV, Monismith SG (2002) A comment on the use of flushing time, residence time, and age as transport time scales. Limnol Oceanogr 47: 1545-1553

Orfila A, Jordi A, Basterretxea G, Vizoso G, Marba N, Duarte C, Werner F, Tintore J (2005) Residence time and Posidonia oceanica in Cabrera Archipelago National Park, Spain. Cont Shelf Res 25:1339

Orsini L, Sarno D, Procaccini G, Poletti R, Dahlmann J, Montresor M (2002) Toxic Pseudo-nitzschia multistriata (Bacillariophyceae) from the Gulf of Naples: morphology, toxin analysis nd phylogenetic relationships with other Pseudonitzschia species. Eur J Phycol 37:247-257

Parker M, Tett P (1987) Special meeting on the causes, dynamics and effects of exceptional marine blooms and related events. Cons Int Expl Mer 187:5-8

Penna A, Ingarao C, Ercolessi M, Rocchi M, Penna N (2006) Potentially harmful microalgal distribution in an area of the NW Adriatic coastline: sampling procedure and correlations with environmental factors. Estuar Coast Shelf Sci 70:307-316

Raimbault P, Rodier M, Taupier-Letage I (1988) Size fraction and phytoplankton in the Ligurian Sea and the Algerian

Editorial responsibility: Otto Kinne (Editor-in-Chief), Oldendorf/Luhe, Germany basin (Mediterranean Sea): size distribution versus total concentration. Mar Microb Food Webs 3:1-7

Ramis C, Jansa A, Alonso S (1990) Sea breeze in Mallorca: a numerical study. Meteorol Atmos Phys 42:249-258

Sarkar RR, Petrovskii SV, Biswas M, Gupta A, Chattopadhyay $\mathrm{J}$ (2006) An ecological study of a marine plankton community based on the field data collected from Bay of Bengal. Ecol Model 193:589-601

Smayda TJ (1997) Harmful algal blooms: their ecophysiology and general relevance to phytoplankton blooms in the sea. Limnol Oceanogr 42:1137-1153

Smayda TJ, Reynolds CS (2003) Strategies of marine dinoflagellate survival and some rules of assembly. J Sea Res 49:95-106

Steele JH, Henderson EW (1992) The role of predation in plankton models. J Plankton Res 14:157-172

Stolte W, Garcés E (2006) Ecological aspects of harmful algal in situ population growth rates. In: Graneli E, Turner J (eds) Ecology of harmful algae, Vol 189. Springer-Verlag, Berlin, p 139-152

Truscott JE (1995) Environmental forcing of simple plankton models. J Plankton Res 17:2207-2232

Truscott JE, Brindley J (1994) Ocean plankton populations as excitable media. Bull Math Biol 56:981-998

Turner JT (2006) Harmful algae interactions with marine planktonic grazers. In: Graneli E, Turner J (eds) Ecology of harmful algae. Springer-Verlag, Berlin, p 259-270

Uye S, Takamatsu K (1990) Feeding interactions between planktonic copepods and red-tide flagellates from Japanese coastal waters. Mar Ecol Prog Ser 59:97-107

Vidal M, Duarte CM (2000) Nutrient accumulation at different supply rates in experimental Mediterranean planktonic communities. Mar Ecol Prog Ser 207:1-11

Vila M, Camp J, Garcés E, Masó M, Delgado M (2001) High resolution spatio-temporal detection of potentially harmful dinoflagellates in confined waters of the NW Mediterranean. J Plankton Res 23:497-514

Werner FE, Viúdez A, Tintoré J (1993) An exploratory numerical study of the currents off the southern coast of Mallorca including the Cabrera Island complex. J Mar Syst 4:45-66

Yoshida T, Jones LE, Ellner SP, Fussmann GF, Hairston Jr NG (2003) Rapid evolution drives ecological dynamics in a predator prey system. Nature 424:303-306

Submitted: March 1, 2007; Accepted: July 23, 2007

Proofs received from author(s): December 10, 2007 